\title{
THE EFFECT OF DEMOGRAPHICS ON INVESTMENT CHOICE AMONG INVESTORS
}

\author{
* Dr. Amutha
}

\begin{abstract}
The economic boom in India has boon to many in terms of increased job and business prospects. The past decade has witnessed changes in consumer lifestyle and has influenced many activities, including investment activity. People used to invest savings in various avenues. There are considerable variations in the availability of investment avenues in pre-liberalization and post-liberalization period. Even changes in demographic profile of India substantiate these changes in investment avenues, their growth and a spurt in the new avenues. This article tries to study the relationship between demographic profiles and investment choice of the investors.
\end{abstract}

\section{INTRODUCTION}

Investment is not a game but a serious subject that can have a major impact on an investors' wealth. Virtually everyone makes investments. Even if the individual does not select specific assets, such as shares, bonds, mutual funds etc., investments are still made through participation in pension plans and employee savings programmes or through purchase of life insurance or a home or by some other mode of investment like investing in real estate, gold, or in banks or in savings schemes of post offices. Each of these investments has common characteristics such as potential returns and the risk which one must bear. Today, financial services more highly diversified than ever. This diversification means that individual investors' have a wider range of investment instrument and greater choice of how to invest their money. There are several key factors that influence investment behaviour and the decision making process of individual investors'. With this back ground the present study explores the relationship between the investment preferences of respondents across the demographics, that is, age, gender income etc.,.

\section{Need for the study}

The investment preference about financial assets is influenced by many factors, such as family size, number of earning members in the family, nature of family, stage in life cycle, experience of investing, education level, family income, nature of occupation, lifestyles and personality characteristics. (Turan and Bodla, 2004). The study of various characteristics of household sector, which is the only surplus sector of the economy, has implications for the financial development of the economy, fund managers

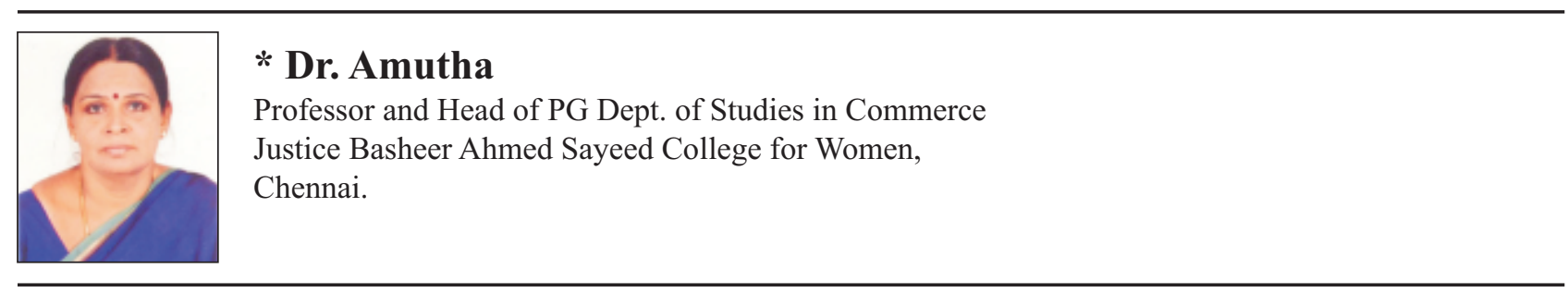


issuing companies and the markets. This study will help not only the investors but also the different financial institutions, organizations and consultants in identifying and understanding the main demographic factors that induces the investors to invest in different avenues and their decision making process.

\section{Literature Review}

The researcher has incorporated the highlights of some well-known empirical studies relating to various influential factors and their impact on investors' behaviour. Chitrak and RamyaSreedevi (2011) have analyzed the influence of personality traits on the method of investment. Accordingly, the important trait that influences the investment is emotional stability. The study by Manish Mittal and Vyas (2011) provides some interesting insights into gender differences in investment behaviour and preference for risk. Bodla and sushant Nagpal (2011) is of the opinion that demographic factors need to be taken care of by marketers and designers of financial product. Filback, et.al (2008) study reveals that investors invest in different avenues for fulfilling financial, social and psychological need. Meenu Verma (2008) investigated the effect of demographics and personality type on investment choice. Diane and Debra (2003) in their research found that investors with education higher than secondary level hold more risky portfolios. Study by Drabu, Haseeb (2003) revealed that a person is more likely to invest in companies known to him and sky away from the unknown avenues. Powell and Ansic (2002) says that those financial products which are good in customer service, management, quality value of efficiency and prompt distribution alone can win. It was found that there is no relation between the demographic and personality variables when driving the effect on investment choice. The results also shows that differences in investment choice are significant for various combinations of independent variables like occupation, gender and education, age and education, education and occupation, education and personality. Shapira and Venezia (2001) in their study analyzed the investment behavior of the clients in a major brokerage firm. The results show that the disposition effect was higher for individual investors and the professionally managed accounts were more diversified in investment and had slightly higher returns compared to independent investors. It also indicates that male and female differ in their preferences for risk. They also found that the percentage of equity holdings in the portfolio increase with age until retirement and thereafter decrease with age. Barber and owen (2000) in their study, analyzed the common stock investment performance among the individual investors and concluded that trading is hazardous to investors' wealth. Byrnes and David (1999) studied and investigated the relationship between risk and gender and concluded that women tend to take less risk than men. EmbreyLori and Fox Jonathan (1997) found that age, sex, income and education affects investors' preferences. Grinbla et.al (1995), in their study, analyzed the extent to which the mutual funds investors purchase stocks based on their past return and the influence of herd behaviour.

\section{Research Question and objectives}

Do demographic variables of investors affect their Investment choice? Based on this research Question the objectives of the study are

* To analyze the investment choice of individual investors' across their demographic characteristics.

* To explore the investment choice of investors.

\section{Research Methodology}

This study is descriptive in nature. In order to collect the information from individual 
investors, a well structured and pretested questionnaire was used. In the present study, composition of investment means how the funds are committed by investors in different financial investment alternatives. The term financial investment used here includes those funds which are held in different securities such as equity shares, preference shares, debentures, fixed deposits, mutual funds, etc., with the expectation of earning future returns either in the form of regular income, capital appreciation or both. The sampling method used can best be described as a mix of Judgmental and convenient sampling. The structured questionnaire which was administered during the month of March 2013 on 300 respondents were randomly selected from Chennai city. Out of this 283 responses were finally considered for the study, hence the acceptance rate was 94 per cent. The primary data obtained from the questionnaire was analyzed by using the simple descriptive tool like average and percentage. In addition, Friedman's test and chisquare test was applied to study the preferences of investors in various financial investment. ' $t$ ' test helps to study the relationship between the demographic factors on the choice of Investment. Further, the secondary data from various internet websites, journals, magazines and other published sources were obtained to gain a better understanding of the concerned subject.

\section{Hypothesis}

The following hypotheses were formulated to study whether the choice of investment depends upon variables such as gender, age, income, education, and occupation.

H1 : Investors' preferences for all the investment avenues are same.

$\mathrm{H} 2$ : There is no significant difference among the investors' belonging to different age groups in their choice of investment alternatives.
H3 : There is no significant influence of marital status of the investors.

H4 : There is no significant difference between the males and females in their choice of investment avenues.

H5 : There is no significant difference among the investors belonging to different income groups in their choice of investment.

H6 : There is no significant difference between the investors of different occupations in their choice of investment alternatives.

The hypotheses were tested at 5\% level of significance. The independent variable of the study included age, marital status, gender, income and occupation. The dependent variables were the various investment avenues.

\section{Limitation of the study}

The scope of present study is limited to the individual investors dwelling in Chennai city of Tamilnadu. In addition the study has taken a few limited but representative financial investment alternatives.

\section{The Sample Investors-A Profile}

The investor profile is of interest as it provides an understanding of the attitudes and investment behaviour of the households. The demographic variables such as age, education, income, occupation etc., influence the attitude towards investment and hence investment decisions build this profile (SEBI- NCAER Survey, June 2000). Investment made by investor is the most significant decision they make about their wealth. The truth is that asset allocation impacts their wealth the most, at all times. Investors make investment decisions mostly by default, without thinking it as a strategy about to improve their 
wealth. Young investors buy property, goaded into believing that they are building an asset and that the EMI is a compulsory savings. Then there are retired investors, who refuse to look beyond fixed income products and deposits, to ensure safety and steady return. Several hold large amounts of cash in their accounts since they haven't made up their minds. All these are situations where the focus is on asset, not needs and future.

Among the demographic variables, age, income, marital status, occupation and employment status have been considered as the basis for influencing the investment preferences and behavior of the individual investors (Ronald et al., 1996; Furqan Qamar, 2003). Accordingly, a profile of sample investors is prepared (Table I).

Table - I

Demographic Profile of the respondents

\begin{tabular}{|c|c|c|c|}
\hline \multicolumn{2}{|c|}{ Particulars } & \multirow{2}{*}{$\begin{array}{r}\begin{array}{c}\text { No. of } \\
\text { Respondents }\end{array} \\
138 \\
\end{array}$} & \multirow{2}{*}{$\begin{array}{r}\text { Percentage } \\
48.80\end{array}$} \\
\hline A) Age & Upto 35 years & & \\
\hline & $36-50$ years & 82 & 29.00 \\
\hline & $51-60$ years & 43 & 15.20 \\
\hline & Above 61 years & 20 & 7.10 \\
\hline & Total & 283 & 100.00 \\
\hline \multirow[t]{3}{*}{ B) Martial Status } & Single & 71 & 25.10 \\
\hline & Married & 212 & 74.90 \\
\hline & Total & 283 & 100.00 \\
\hline \multirow[t]{3}{*}{ C) Gender } & Female & 113 & 39.90 \\
\hline & Male & 170 & 60.10 \\
\hline & Total & 283 & 100.00 \\
\hline \multirow[t]{6}{*}{ D) Income Per Month } & Less than Rs.20,000 & 83 & 29.30 \\
\hline & $\ldots$ & 91 & 32.20 \\
\hline & Rs.30,001 - Rs.40,000 & 54 & 19.10 \\
\hline & Rs. 40,001 - Rs. 50,000 & 32 & 11.30 \\
\hline & Above Rs.50,001 & 23 & 8.10 \\
\hline & Total & 283 & 100.00 \\
\hline \multirow[t]{5}{*}{ E) Occupation } & Business / Profession & 54 & 19.10 \\
\hline & $\begin{array}{l}\text { Private Companies } \\
\text { Employee }\end{array}$ & 142 & 50.20 \\
\hline & Government Employee & 43 & 15.20 \\
\hline & Others & 44 & 15.50 \\
\hline & Total & 283 & 100.00 \\
\hline
\end{tabular}

Source : Primary data 
The present study segments the respondents into four classes according to their age. These are (i) upto 35 years (ii) $36-50$ years, (iii) 51 to 60 years and above 61 years. Table, 1 (A) reveals that while the higher percentage (48.80) of the respondents belongs to below 35 years, 29 per cent fall in the category of middle age-group of 36-50 years. Those between 51 and 60 years of age constitute only 15.20 per cent of the total sample size. The representation of senior citizens (i.e above 61 years age) in the sample is respectable ( 7.10 per cent) and adequate. Thus, the sample is representative of the investors' population.

Marital status of investors is another important factor in investment decision. Hence, a profile of sample respondents is prepared according to their marital status. The Table 1(B) clearly indicates that study covers 25.10 per cent single and 74.90 per cent married investor. So, the study largely covers the married investors.

The distribution of sample according to sex as presented in Table I (C), indicates that 60.10 per cent of the respondents are males and the rest, 39.90 per cent are female investors. Thus, the sample is dominated by male respondents.

Family income is also an important variable in segmenting the investors' market. Accordingly, the profile of the sample investors are classified into five groups as follows (i) Low income group (monthly income below Rs.20,000); (ii) Lower Middle income group (between Rs.20,001 to Rs.30,000); (iii) Middle income group (Rs.30,001 to Rs.40,000); (iv) Upper Middle income group (Rs.40,001 to Rs.50,000); and (v) the high income group (above Rs.50,001). It is clear from Table 1(D) that very less number of respondents $(8.10$ per cent) have income above Rs.50,001. Around 11.30 per cent respondents are in the category of Rs.40,001 to Rs.50,000 and 19.10 per cent sample investors belong to the income class of Rs.30,001 to Rs.40,000. The majority (32.20 percent) sample investors fall in the low middle income group. Thus the study is representative of Indian investors having scope for planning their portfolio.

Occupation influences the preferences of investment choice and risk bearing capacity of individual investors. Occupation for the purpose of present investigation has been classified into four categories - business / profession, private company employees, Government employees and others. Business / profession include doctors, lawyers, chartered accountants, engineers etc., and providing service to the society. Those who are employed in private and Government are classified status-wise. The retired persons are classified as 'others'. Table 1(E) which represents the distribution of the sample investors among different occupations shows that the highest proportion $(50.20$ percent $)$ of the sample respondents is employed in private companies. Those who are in business constitute the second highest group (19.10 percent) of sample investors, followed, in a descending order by others and government employees. Hence, the sample is dominated by private company employees and professionals.

\section{Investment pattern of sample respondents at the over all Level}

In analyzing the investment pattern of the sample respondents the investors were asked to reveal their choice amongst as many as nineteen separate investments. Broadly, these investments are divided into four categories -(i) Fixed income but taxable is made up of regular income schemes of mutual funds, preference shares, fixed deposits with government and non-government undertakings, fixed deposits with private finance companies, banks and post offices, taxable bonds of government, recurring deposits and chit funds (ii) tax free investments- includes investments such as NSC, NSS, PPF, EPF, life insurance policies, infrastructure bonds and equity linked 
savings schemes (ELSS). While the third group covers the most risky investment such as equity shares, debentures and growth schemes of mutual fund and group four represents the investments in physical assets like gold and real estate (Bodla, Sushant Nagpal (2010).)

Table - II

Investment preferences of sample respondents at the Overall Level

\begin{tabular}{|c|c|c|c|c|c|c|c|c|c|c|c|}
\hline SI. & Investment Alternatives & \multicolumn{2}{|c|}{ HP } & \multicolumn{2}{|c|}{$\mathbf{P}$} & \multicolumn{2}{|c|}{$\mathrm{N}$} & \multicolumn{2}{|c|}{ NP } & \multicolumn{2}{|c|}{ NAP } \\
\hline & & $\mathbf{N}$ & $\%$ & $\mathbf{N}$ & $\%$ & $\mathbf{N}$ & $\%$ & $\mathbf{N}$ & $\%$ & $\mathbf{N}$ & $\%$ \\
\hline$\Delta$ & $\begin{array}{l}\text { Regular income Schemes of } \\
\text { Mutual Funds }\end{array}$ & 115 & 40.60 & 83 & 29.30 & 42 & 14.80 & 28 & 9.90 & 15 & 5.30 \\
\hline 2. & Preference Shares & 20 & 7.10 & 97 & 34.30 & 77 & 27.20 & 60 & 21.20 & 29 & 10.20 \\
\hline 3. & $\begin{array}{l}\text { Fixed Deposits with } \\
\text { Government and Non } \\
\text { Government undertakings }\end{array}$ & 85 & 30.00 & 87 & 30.70 & 78 & 27.60 & 17 & 6.00 & 16 & 5.70 \\
\hline 4. & $\begin{array}{l}\text { Deposit with Private Finance } \\
\text { Companies }\end{array}$ & 56 & 19.80 & 71 & 25.10 & 78 & 27.60 & 50 & 17.70 & 28 & 9.90 \\
\hline 5. & $\begin{array}{l}\text { Fixed Deposits with Bank / } \\
\text { Post Office Schemes }\end{array}$ & 139 & 49.10 & 68 & 24.00 & 42 & 14.80 & 25 & 8.80 & 9 & 3.20 \\
\hline 6. & $\begin{array}{l}\text { Taxable bonds of } \\
\text { Government Undertakings }\end{array}$ & 56 & 19.80 & 63 & 22.30 & 77 & 27.20 & 62 & 21.90 & 25 & 8.80 \\
\hline 7 & Recurring Deposits & 114 & 40.30 & 70 & 24.70 & 53 & 18.70 & 34 & 12.00 & 12 & 4.20 \\
\hline 8. & $\begin{array}{l}\text { Indira Vikas Patra / Kisa } n \\
\text { Vikas Patra }\end{array}$ & 36 & 12.70 & 49 & 17.30 & 78 & 27.60 & 71 & 25.10 & 49 & 17.39 \\
\hline 0 & Chit Funds & 66 & 23.30 & 69 & 24.40 & 43 & 15.2 & 68 & 24.00 & 37 & 13.10 \\
\hline B 10. & NSC / NSS & 57 & 20.10 & 72 & 25.40 & 70 & 24.70 & 56 & 19.80 & 28 & 9.90 \\
\hline 11 & $\mathrm{EPF} / \mathrm{PPF}$ & 83 & 29.30 & 78 & 27.60 & 55 & 19.40 & 47 & 16.60 & 20 & 7.10 \\
\hline 17 & Life Insurance Policies & 104 & 36.70 & 96 & 33.90 & 39 & 13.80 & 33 & 11.70 & 11 & 3.90 \\
\hline 13 & $\begin{array}{l}\text { Tax Free Bonds of } \\
\text { Government Undertakings }\end{array}$ & 47 & 16.60 & 76 & 26.90 & 78 & 27.60 & 53 & 18.70 & 29 & 10.20 \\
\hline 14 & $\begin{array}{l}\text { Equity Linked Savings } \\
\text { Schemes }\end{array}$ & 33 & 11.70 & 78 & 27.60 & 86 & 30.40 & 58 & 20.50 & 28 & 9.90 \\
\hline C. 15 . & Equity Shares & 40 & 14.10 & 84 & 29.70 & 84 & 29.70 & 50 & 17.70 & 25 & 8.80 \\
\hline 16. & $\begin{array}{l}\text { Mutual Fund Growth } \\
\text { Schemes }\end{array}$ & 49 & 17.30 & 95 & 33.60 & 69 & 24.40 & 40 & 14.10 & 30 & 10.60 \\
\hline 17. & Convertible Debentures & 41 & 14.50 & 65 & 23.00 & 83 & 29.30 & 67 & 23.70 & 27 & 9.50 \\
\hline D.18. & Gold & 152 & 53.70 & 82 & 29.00 & 27 & 9.50 & 12 & 4.20 & 10 & 3.50 \\
\hline
\end{tabular}

Source: Primary data 
Table II explores the Investment preferences of sample respondents at overall level. Table (II) reveals the following results

* The highest percentage of investors (49.10 percent) prefers to put their savings in Banks and post office scheme, which is followed by regular income scheme of mutual funds, (40.60 percent) recurring deposits ( 40.30 percent) and life insurance policies ( 36.70 percent)

* $\quad 30$ and 29.30 per cent of the respondents are interested in fixed deposits with Government and Non-government undertaking and EPF / PPF respectively.

* As regards the stock market instrument, investment in equity shares, equity linked savings schemes, growth schemes of mutual fund and convertible debentures of companies are at the lowest ebb.

* The taste of the sample investors for physical assets like real estate and gold is found much alive as around two-fifth of the sample respondents have shown their interest in these assets as investment.

The above mentioned results are quite revealing and find support from the latest data published by the RBI, which states that the government faces the challenges of holding investment rate from slipping further, as small savings continued to erode amid lower rates and persistent high inflation, which promoted households to invest in gold. Household inflation expectation remain high and rising with double digit ratio of price increase still being predicted in the RBI expectations survey over the next 3 months and one year, will diverts funds away from more productive investments to physical assets which covers investment in real estates and gold. It is well known that people always look for alternate avenues of investment that offers high rate of return.

\section{Investors preference in various Investment Avenues}

To explore the investors' preference in various investments avenues, Friedman's test for k- related samples was applied. The analysis of null hypothesis: Investors preference for all the investment alternatives are same is presented below.

Table III

Investors' preference in various investment alternatives

\begin{tabular}{|c|c|l|c|c|}
\hline \multicolumn{2}{|c|}{ S.No. } & \multicolumn{1}{|c|}{ Investment Alternatives } & $\begin{array}{c}\text { Mean } \\
\text { Rank }\end{array}$ & $\begin{array}{c}\text { Chi Square } \\
\text { Value }\end{array}$ \\
\hline \multirow{2}{*}{ A } & & Fixed Income but Taxable & 6.08 & \\
\cline { 2 - 4 } & 1 & Regular income schemes of Mutual funds & 4.18 & \multirow{2}{*}{5} \\
\cline { 2 - 4 } & 2 & Preference Shares & 5.54 & \multirow{2}{*}{$\begin{array}{l}\text { Fixed deposits with Government and } \\
\text { Non- Government }\end{array}$} \\
\cline { 2 - 4 } & 4 & $\begin{array}{l}\text { Deposits Undertakings with private Finance } \\
\text { Companies }\end{array}$ & \\
\hline
\end{tabular}




\begin{tabular}{|c|c|c|c|c|}
\hline \multicolumn{2}{|c|}{ S.No. } & Investment Alternatives & $\begin{array}{l}\text { Mean } \\
\text { Rank }\end{array}$ & $\begin{array}{c}\text { Chi Square } \\
\text { Value }\end{array}$ \\
\hline & 5 & Fixed deposits with Bank/ Post office Schemes & 6.22 & \multirow{5}{*}{$\begin{array}{c}289.337 \\
(p=001)\end{array}$} \\
\hline & 6 & Taxable bonds of government undertakings & 4.47 & \\
\hline & 7 & Recurring deposits & 5.79 & \\
\hline & 8 & Indira Vikas Patra / Kisan Vikas Patra & 3.68 & \\
\hline & 9 & Chit funds & 4.48 & \\
\hline \multirow[t]{6}{*}{ B } & & Tax Free Investment & & \multirow{6}{*}{$\begin{array}{c}66.496 \\
(p=001)\end{array}$} \\
\hline & 10 & NSC / NSS & 2.83 & \\
\hline & 11 & $\mathrm{EPF} / \mathrm{PPF}$ & 3.16 & \\
\hline & 12 & Life Insurance Policies & 3.52 & \\
\hline & 13 & Tax free bonds of Government undertakings & 2.82 & \\
\hline & 14 & Equity linked saving schemes & 2.66 & \\
\hline \multirow[t]{4}{*}{$\mathbf{C}$} & & Risky Investments & & \multirow{4}{*}{$\begin{array}{c}9.894 \\
(p=007)\end{array}$} \\
\hline & 15 & Equity Shares & 1.98 & \\
\hline & 16 & Mutual Fund growth schemes & 2.12 & \\
\hline & 17 & Convertible debentures of companies & 1.90 & \\
\hline \multirow[t]{3}{*}{$\mathbf{D}$} & & Physical Assets & & \multirow{3}{*}{$\begin{array}{c}2.240 * \\
(p=.134)\end{array}$} \\
\hline & 18 & Gold & 1.47 & \\
\hline & 19 & Real Estate & 1.53 & \\
\hline
\end{tabular}

\footnotetext{
**Significant at 1\% level

*Significant at 5\% level
}

The results in Table III shows that the null hypothesis (H0) is not accepted (1\% level) as the investors' preferences for all investments under fixed income but taxable instrument, tax free investment and most risky investment are not the same. Further, the mean ranks in the Table III(A) shows that fixed deposits with banks/post office schemes, regular income schemes of mutual funds and recurring deposits are the top preferences of the investors' under fixed income but taxable investment. While preference shares and Indira Vikas Patra/Kisan Vikas Patra are the least preferred investment in this category. In the tax free investment category Table III (B) life insurance policies is the most preferred, followed by EPF/PPF. It was also observed that, Table III(c) investors give least preference to risky investment though the investor's preferences are not the same. The results in the Table III(D) shows that the null hypothesis (H0) is accepted (5\% level). Hence, it can be inferred that the investors' preferences for investments under physical assets are the same. This reflects the way in which India's high rate of inflation exudes incentives for 
households to put funds into financial savings as well as the recent high degree of household interest in allocating funds towards physical savings such as real estate and gold.

\section{Investment Preferences and Demographics}

The objective of studying investment preferences of individual investors across their demographics are analyzed across a number of dimensions such as age, marital status, gender, income, occupation and employment . To examine in depth whether these demographic variables exert significant impact on the choice of various investment avenues, ' $F$ ' test and ' $t$ ' test are applied. The relationship between age and investment behaviour has attracted much attention. Numerous studies have shown influence of age on the preference of investors about financial instrument.

Table IV

Influence of Age on Investments

\begin{tabular}{|c|c|c|c|c|c|c|}
\hline \multirow{5}{*}{ A } & & Age & $\mathbf{N}$ & Mean & S D & F-Value \\
\hline & \multirow{4}{*}{$\begin{array}{l}\text { Fixed Income but } \\
\text { Taxable Instrument }\end{array}$} & Upto 35 years & 138 & 3.47 & .551 & \multirow{4}{*}{$\begin{array}{c}.320 \\
(\mathrm{p}=.811)\end{array}$} \\
\hline & & $35-50$ years & 82 & 3.48 & .444 & \\
\hline & & $50-60$ years & 43 & 3.41 & .511 & \\
\hline & & Above 60 years & 20 & 3.38 & .644 & \\
\hline \multirow{4}{*}{ B } & \multirow{4}{*}{ Tax Free Instruments } & Upto 35 years & 138 & 3.41 & .677 & \multirow{4}{*}{$\begin{array}{c}.009 \\
(\mathrm{p}=.961)\end{array}$} \\
\hline & & $35-50$ years & 82 & 3.41 & .745 & \\
\hline & & $50-60$ years & 43 & 3.34 & .621 & \\
\hline & & Above 60 years & 20 & 3.41 & .803 & \\
\hline \multirow{4}{*}{$\mathrm{C}$} & \multirow{4}{*}{$\begin{array}{l}\text { Most Risky } \\
\text { Instruments }\end{array}$} & Upto 35 years & 138 & 3.24 & .845 & \multirow{4}{*}{$\begin{array}{c}.276 \\
(\mathrm{p}=.843)\end{array}$} \\
\hline & & $35-50$ years & 82 & 3.22 & .828 & \\
\hline & & $50-60$ years & 43 & 3.16 & .820 & \\
\hline & & Above 60 years & 20 & 3.08 & 1.080 & \\
\hline \multirow{4}{*}{ D } & \multirow{4}{*}{ Physical Assets } & Upto 35 years & 138 & 4326 & .837 & \multirow{4}{*}{$\begin{array}{c}.066 \\
(p=.978)\end{array}$} \\
\hline & & $35-50$ years & 82 & 4.31 & .717 & \\
\hline & & $50-60$ years & 43 & 4.29 & .839 & \\
\hline & & Above 60 years & 20 & 4.27 & .802 & \\
\hline
\end{tabular}

The portfolio choice across various age groups in Table IV, reveals some very interesting point. Since all the p-values are greater than .05, the null hypothesis is accepted at $5 \%$ level of significance and it shows that age does not influence the investment. 
Table V

Influence of Marital Status on Investments

\begin{tabular}{|c|c|c|c|c|c|c|}
\hline & $\begin{array}{l}\text { Investment } \\
\text { Alternatives }\end{array}$ & Marital Status & $\mathbf{N}$ & Mean & S D & F-Value \\
\hline \multirow[t]{2}{*}{$\mathbf{A}$} & $\begin{array}{l}\text { Fixed Income but } \\
\text { Taxable Instrument }\end{array}$ & Single & 71 & 3.41 & .562 & $\begin{array}{c}.964 \\
(p=.336)\end{array}$ \\
\hline & & Married & 212 & 3.47 & .508 & \\
\hline \multirow[t]{2}{*}{ B } & $\begin{array}{l}\text { Tax Free } \\
\text { Opportunities }\end{array}$ & Single & 71 & 3.34 & .698 & $\begin{array}{c}.817 \\
(p=.414) \\
\end{array}$ \\
\hline & & Married & 212 & 3.42 & .695 & \\
\hline \multirow[t]{2}{*}{ C } & $\begin{array}{l}\text { Most Risky } \\
\text { Instruments }\end{array}$ & Single & 71 & 3.19 & .88 & $\begin{array}{c}.263 \\
(p=.793)\end{array}$ \\
\hline & & Married & 212 & 3.22 & .84 & \\
\hline \multirow[t]{2}{*}{ D } & Physical Assets & Single & 71 & 4.04 & .91 & $\begin{array}{l}2.927 * * \\
(\mathrm{p}=.004)\end{array}$ \\
\hline & & Married & 212 & 4.36 & .739 & \\
\hline
\end{tabular}

Source : Primary data

**Significant at $1 \%$ level

The details regarding preferences for various mentioned groups of investments. Contrary to investment alternatives according to marital this, the pattern of preferences attached with status of the respondents are presented in Table V. physical assets states that there is significant It shows that the null hypothesis is accepted at 5\% influence of marital status on physical assets. level of significance for fixed income but taxable Further, it also indicates that preference for instrument, Tax free instruments, and most risky physical assets is more among married investors instruments. This indicates that there is no than the investors living as single.

significant influence of marital status on the above

Table VI

Influence of Gender on Investments

\begin{tabular}{|c|c|c|c|c|c|c|}
\hline & $\begin{array}{l}\text { Investment } \\
\text { Alternatives }\end{array}$ & Gender & $\mathbf{N}$ & Mean & S D & t-Value \\
\hline \multirow{2}{*}{$\mathbf{A}$} & \multirow{2}{*}{$\begin{array}{l}\text { Fixed Income but } \\
\text { Taxable Instrument }\end{array}$} & Female & 113 & 3.50 & .505 & \multirow{2}{*}{$\begin{array}{c}1.226 \\
(p=.221)\end{array}$} \\
\hline & & Male & 170 & 3.43 & .532 & \\
\hline \multirow{2}{*}{ B } & \multirow{2}{*}{$\begin{array}{l}\text { Tax Free } \\
\text { Opportunities }\end{array}$} & Female & 113 & 3.42 & .647 & \multirow{2}{*}{$\begin{array}{c}.481 \\
(p=.831)\end{array}$} \\
\hline & & Male & 170 & 3.38 & .727 & \\
\hline \multirow[t]{2}{*}{$\mathbf{C}$} & \multirow{2}{*}{$\begin{array}{l}\text { Most Risky } \\
\text { Instruments }\end{array}$} & Female & 113 & 3.24 & .800 & \multirow{2}{*}{$\begin{array}{c}.063 \\
(p=.683)\end{array}$} \\
\hline & & Male & 170 & 3.19 & .885 & \\
\hline \multirow[t]{2}{*}{ D } & \multirow{2}{*}{ Physical Assets } & Female & 113 & 4.26 & .787 & \multirow{2}{*}{$\begin{array}{c}.280 \\
(p=.780)\end{array}$} \\
\hline & & Male & 170 & 4.29 & .807 & \\
\hline
\end{tabular}


The study also makes an attempt to examine whether the preferences for various investment avenues differ between male and female investors. A glance through Table VI clearly indicates that, t-values are greatest than .05 for all investment choice. Hence the null hypothesis is accepted at $5 \%$ level of significance, which means gender does not influence the investment choice.

Table VII

Influence of Income on Investments

\begin{tabular}{|c|c|c|c|c|c|c|}
\hline & $\begin{array}{l}\text { Investment } \\
\text { Alternatives }\end{array}$ & Income & $\mathbf{N}$ & Mean & S D & F-Value \\
\hline \multirow{5}{*}{$\mathbf{A}$} & \multirow{5}{*}{$\begin{array}{l}\text { Fixed Income but } \\
\text { Taxable Instrument }\end{array}$} & Less than Rs.20,000 & 83 & 3.40 & .532 & \multirow{5}{*}{$\begin{array}{c}3.49 \\
(p=.018)\end{array}$} \\
\hline & & - & 91 & 3.37 & .560 & \\
\hline & & Rs.30,001 - Rs.40,000 & 54 & 3.48 & .400 & \\
\hline & & Rs.40,001 - Rs.50,000 & 32 & 3.71 & .467 & \\
\hline & & Above Rs.50,001 & 23 & 3.57 & .560 & \\
\hline \multirow{5}{*}{ B } & \multirow{5}{*}{$\begin{array}{l}\text { Tax Free } \\
\text { Opportunities }\end{array}$} & Less than Rs.20,000 & 83 & 3.36 & .645 & \multirow{5}{*}{$\begin{array}{c}2.497 \\
(p=.043)\end{array}$} \\
\hline & & Rs.20,001 - Rs.30,000 & 91 & 3.31 & .713 & \\
\hline & & Rs.30,001 - Rs.40,000 & 54 & 3.34 & .653 & \\
\hline & & Rs.40,001 - Rs.50,000 & 32 & 3.67 & .560 & \\
\hline & & Above Rs.50,001 & 23 & 3.64 & .939 & \\
\hline \multirow{5}{*}{$\mathbf{C}$} & \multirow{5}{*}{$\begin{array}{l}\text { Most Risky } \\
\text { Instruments }\end{array}$} & Less than Rs. 20,000 & 83 & 3.05 & .855 & \multirow{5}{*}{$\begin{array}{c}3.672 * \\
(p=.006)\end{array}$} \\
\hline & & Rs.20,001 - Rs.30,000 & 91 & 3.18 & .824 & \\
\hline & & Rs.30,001 - Rs.40,000 & 54 & 3.14 & .812 & \\
\hline & & Rs.40,001 - Rs.50,000 & 32 & 3.51 & .846 & \\
\hline & & Above Rs.50,001 & 23 & 3.68 & .849 & \\
\hline \multirow{5}{*}{ D } & \multirow{5}{*}{ Physical Assets } & Less than Rs.20,000 & 83 & 4.22 & .812 & \multirow{5}{*}{$\begin{array}{l}1.979 * * \\
(p=.098\end{array}$} \\
\hline & & Rs.20,001 - Rs.30,000 & 91 & 4.15 & .791 & \\
\hline & & Rs.30,001 - Rs.40,000 & 54 & 4.41 & .856 & \\
\hline & & Rs.40,001 - Rs.50,000 & 32 & 4.54 & .639 & \\
\hline & & Above Rs.50,001 & 23 & 4.34 & .760 & \\
\hline
\end{tabular}

**Significant at 5\% level *Significant at 1\% level

Table VII which represents the investment pattern according to different income groups, indicates that the income plays a significant role while investing in fixed income but taxable instruments and Tax free investments. The null hypothesis is accepted at $5 \%$ level of significance since $p$-value is greatest than .05 for physical asset. This shows that there is no significant influence of income on physical assets. Since the P-value for most risky instruments is less than. 0.1 The null hypothesis is rejected. Hence, it may be inferred that there is significant influence of income while investing in most risky instruments. 
Table VIII

Influence of Occupation on Investments

\begin{tabular}{|c|c|c|c|c|c|}
\hline & Occupation & $\mathbf{N}$ & Mean & S D & F-Value \\
\hline \multirow{4}{*}{$\begin{array}{l}\text { Fixed Income but } \\
\text { Taxable Instrument }\end{array}$} & Business & 54 & 3.40 & .548 & \multirow{4}{*}{$\begin{array}{c}2.518 \\
(p=.058)\end{array}$} \\
\hline & Private Companies & 142 & 3.40 & .532 & \\
\hline & Government Employee & 43 & 3.56 & .420 & \\
\hline & Others & 44 & 3.60 & .516 & \\
\hline \multirow{4}{*}{$\begin{array}{l}\text { Tax Free } \\
\text { Opportunities }\end{array}$} & Business & 54 & 3.28 & .736 & \multirow{4}{*}{$\begin{array}{c}2.832 * \\
(p=.039)\end{array}$} \\
\hline & Private Companies & 142 & 3.36 & .668 & \\
\hline & Government Employee & 43 & 3.66 & .623 & \\
\hline & Others & 44 & 3.40 & .754 & \\
\hline \multirow{4}{*}{$\begin{array}{l}\text { Most Risky } \\
\text { Instruments }\end{array}$} & Business & 54 & 3.30 & .864 & \multirow{4}{*}{$\begin{array}{c}2.485 \\
(p=.061)\end{array}$} \\
\hline & Private Companies & 142 & 3.11 & .834 & \\
\hline & Government Employee & 43 & 3.49 & .864 & \\
\hline & Others & 44 & 3.14 & .836 & \\
\hline \multirow[t]{4}{*}{ Physical Assets } & Business & 54 & 4.19 & .881 & \multirow{4}{*}{$\begin{array}{c}.543 \\
(p=.653)\end{array}$} \\
\hline & Private Companies & 142 & 4.27 & .826 & \\
\hline & Government Employee & 43 & 4.31 & .698 & \\
\hline & Others & 44 & 4.39 & .695 & \\
\hline
\end{tabular}

*Significant at 5\% level

The pattern of investment preferences obtained across different occupational groups of investors reveals that the null hypothesis-investment avenues and occupation are independent of each other is accepted in the first and last two groups. Further it is seen that occupation has a significant influence on tax free investments, since the $\mathrm{p}$. value is lesser than 0.05 for that category. The PValue for tax free opportunities is less than.0.5, indicates that there is significant influence of occupation on tax free opportunities. Also, the preference of tax free investment is high among investors working in Government sector than in business.

\section{Conclusion}

In nutshell, the study brings out that, inspite of phenomenal growth in security market, the individual investors' prefer regular income investments and physical assets. Among the financial assets fixed deposits with government and non-government undertaking, fixed deposits with Banks/ post office, recurring deposits and life insurance policies are more preferred by the investors. Mutual funds growth schemes attracted substantial percentage of investors. The level of household income being allocate to physical assets has remain high. As regards demographics - age, income, occupation, employment status, gender and marital status are independent of the investor's choices over alternative investment avenues. Physical assets are found to be very attractive. Income and marital status has high influence over this investment decision of investors. Hence, it can be concluded be that the demographic variables of the investors need to be taken care of by marketers and designers of financial products, as investors or customers are the key of success for any business. 


\section{References}

- Barber Brad M and Odean Terrance (2000)," Trading is Hazardous to wealth: The common stock Investment Performance of Individual Investors," The Journal of Finance, Vol. LV, No.2, PP. 773806.

- Bodla B.S, Sushant Nagpal (2010),” Investors' Demographics and Investment pattern- an empirical study", Envision Apcejay's Commerce and Management journal, PP 66-78.

- Byrnes J, Miller D and Schafer to (1999)," Gender Differences in Risk Taking: A Metaanalysis," Psychological Bulletin, Vd.125, No.3, PP.367-83.

- Chitrak and Ramya Sreedevi V. (2011) “ Does Personality Traits Influence the choice of Investment", The Journal of Behaviourd Finance, Vol v/11 No.2 PP 47-56.

- Dwyer Peggy D, Gilkeson James H and List John A (2002), "Gender Differences in Revealed Risk taking. Evidence from Mutual fund Investor", Economic letters, Vol.76, PP.151-158.

- $\quad$ Embrey Lori L and Fix Janathan J (1997) "Gender Difference in the Investment Deceision - Making Process", Financial Counseling and Planning, Vol. 8, No.2, PP.33-39.

- $\quad$ Filbeck G, Hafied P and Horvath P (2008), "Risk Aversion and Personality Type", Journal of Behavioral Finance - Vol. 6, No.4, PP. $170-180$.

- Grinbla H Mark, Titman Sheridan and Wermers Russ (1995), “ Momentum Investment Strategies, Portfolio Performance and Herbing . A study on Mutual Fund Behaviour", The American Economic Review, Vol.85, No.5, PP.1088 1105.

- Giridhari Mohanta and Sathya Swaroop Debasish (2011), “ A study on Investment Preferences. Among Urban Investors in
Orissa", Prerana, March 2011 PP1 - 9.

Manish Mihal and RK Vyas (2011), “ A study of Psychological Reasous for Gender differences in Preferences for Risk and Investment Decision making", The Journal of Behavioral Finance, Vol v/11 No.3, PP.45 -57 .

Manu Verma (2008), "Wealth Management and Behavioral Finance : The Effect of Demographics and Personality on Investment Choice Among Indian Investors", Journal of Behavioral Finance, Vol. V.No.4, December, 2008, PP. 31 - 57.

Powerll M and Ansic D (2002), "Gender Difference in Risk Behaviour in Financial Decision Making : An Experimental Analysis", Journal of Economic Psychology, Vol. 18, No.6, PP. 605-627.

Ronald C., Wilbur G. Lewellen and Gary G.Scharbaum (1996)," Market Segmentation: Evidence on the Individual Investor," Financial Analysis, Journal, September-October, PP.53-60.

Schooley Diane K and Debra Drecnik Worden (2003), "Generation X: Understanding their Risk Tolerance and Investment Behaviour", Journal of Financial Planning. The Financial Planning Association, September, 2003, Vol. 43, No.4, PP. $8-13$.

Shapira Zur and Venezia Itzhak (2001), "Patterm of Behaviour of Professionally Managed and Independent Investor", Journal of Banking and Finance, Vol.25, No.8, PP 1573 - 1587.

Turan, M.S and Bodla, B.S (2004), " Risk and rewards of Equity Investments - a study of select Asian Stock Markets", Excel Books, PP.139 - 166.

Qamar, Fruqum (2003), "Saving Behaviour and Investment preference amount average urban households, "The Indian Journal of Commerce, Vol. 56, No.1, January - March. 